\title{
ENGLISH LOAN WORDS ON INDONESIAN HEALTH ARTICLES IN ONLINE NEWS PAGES
}

\author{
Sri Supeni \\ Email: supeni@binawan-ihs.ac.id \\ Anna Fauziah \\ Sekolah Tinggi Ilmu Kesehatan Binawan
}

APA Citation: Supeni, Sri.,Fauziah, Anna. (2018). English Loan Words on Indonesian Health Articles in Online News Pages. Journal of English Language and literature, 3(2), 2034.doi: $10.37110 /$ jell.v3i2.54.

Received: 26-06-2018

Accepted: 01-08-2018

Published:01-09-2018

Abstract: This study focuses on the process of English words which are loaned or borrowed into Indonesian language and are used on Indonesian health articles in online news pages such as detik.com, kompas.com and viva.com. The data are analyzed based on the four word forms namely noun, verb, adjective and adverb. Besides, they are also analyzed based on either the morphological process or phonological process. The study applies the descriptive qualitative method applying the content analysis technique. The findings of the research show that there are 606 loan words. Based on word form category there are 425 words $(70.13 \%)$ as noun, adjective with 96 words (15.84\%), verb with 82 words $(13.50 \%)$ adverb with only 3 words $(0.49 \%)$. For morphological process, it can be categorized in some various processes, they are affixation with several prefixes and suffixes. In addition, there are some words with reduplication as many as 7 words $(6.14 \%)$ and abbrevation process, they are 13 words (11.40\%). Phonological process occurs into several parts, they are adoption, translation and adaptation. For adoption, there are 395 words $(65.18 \%)$, adaptation with 166 words (27.39\%) and translation with 45 words $(7.42 \%)$.

Key words: Loan words, phonological process, morphological process

\section{INTRODUCTION}

Language is an important communication tool for exchanging information and conveying messages to others. According to Kushartanti et.al (2005) language is a sound sign system that is agreed to be used by members of groups from certain communities in collaboration. Language plays an important role in the relationship of society, because with language human can interact with each other well.

In their interaction, humans always evolve according to the times, as well 
as the language used. The language used by a group of people will continue to develop along with the wider interaction of the community. In Indonesia there are various languages used to communicate. The contribution of other languages to the Indonesian language resulted in the expansion of the Indonesian treasury, as a result of cultural contacts between languages, inter-regional, tribal and religious, technological, political and other influences. This is corroborated by Hardjopawiro's (2005) claim that Indonesian language in its growth and development has received influence from regional languages (mainly Javanese) and foreign languages (especially English). The presence of contact with other languages gives effect to the emergence of new vocabulary that comes from the foreign language, so that there is absorption from a foreign language called the absorption word or in other words it is also called loan words or borrowed words. Indonesian language continues to grow in line with the development of science and technology. Therefore, there are a lot of foreign languages that enter and are absorbed in the Indonesian language, especially English.

The absorption of English words into Indonesian occurs in two ways. The first is with overall absorption, this is true in both spelling and pronunciation. While the second is with the adjustment of spelling and speech in accordance with the rules of the Indonesian language. For example the use of the word "check" in (English) will be spoken "cek" and then absorbed into the Indonesian language into "cek".

The use of loan words or borrowed words which are found and used in various contact situations is a prove that languages among societies can influence each other. As it is stated by Thomason (2001) that language contact is everywhere: there is no evidence that any languages have developed in total isolation from other languages. It means there is no language which has no loan words or borrowed words.

From the general description, then to analyze the problem of language above, it takes a concept. The concept is studied in sociolinguistics. As one of the study of linguistics, sociolinguistics is one of the science that discusses the relationship of language and society. Trudgill in Sekarrosa (2014) states that sociolinguistics is part of linguistics that examines language as a social and cultural phenomenon, among which the phenomenon is the word absorption or lending as a result of cultural interaction . Loan word or borrowed word is a result of language contact and it refers to the adoption of individual words or groups of 
vocabulary items from one language into another language. The terms borrowed words and loanwords tare interchangeable (Hock, 1986; Trask, 1996 cited by Mohideen, 2009). Thomason \& Kauffman (1998) define borrowing as the incorporation of foreign features into a group's native language by speakers of that language: the native language is maintained but is changed by addition of the incorporated features. Gomez (2012) states that loanwords are therefore seen as established, incorporated or adopted borrowings.

The use of the loan words today is growing rapidly even it can be said that the use of this loan words takes place in all fields where the loan words used are almost all taken from the English term. The use of the loan words is seemingly arbitrary or free because there are no rules and or body that guards and guides it. So even though there are many English words that already have an equivalent in the Indonesian language, a new loan word still exists.

There are some reasons why borrowings are applied. The reasons are : many borrowing from English are superfluous from the point of view communicative efficiency. Sneddon in Dwi et. al (2014) mentions some borrowings are felt to fulfill a need for a particular concept that is new to the society. In other words, the borrowing are more efficient. This is quite similar with Campbell in Sekarrosa (2014) who came up with the idea that language is borrowed for the sake of "need", and he extends that it also for "prestige".

The term of loan word is basically an absorption from one language to another language which is tailored to the user's language. This statement is supported by Mesthrie (2000) which states that language loans are a technical term for combining items from one language to another. While Jendra (2010) states that there are 3 basic groups of loan that is word loan, loan mix and loan shift. In other words it can be stated that the word loan is a borrowing process from another language that was not originally available in that language. This lending process can be intact as well as the result of adoption and adaptation with the recipient language so that finally formed a new vocabulary. Adoption is the process of absorbing foreign language vocabulary taken by the user because it has the same meaning but without changing the way of writing and pronunciation or in other words the word taken exactly the same as the original form. While adaptation is a process of foreign language absorption used by users because it has the same meaning with the Indonesian language but the word uptake has been changed rules and 
rules of writing in accordance with the language that absorbs. Another one is the process of entering a foreign language into the Indonesian language that occurs because the language user takes the existing concept in the source language, then the equivalent of the word thawed according to Indonesian language. This process can also be called by the process of translation because in its use the absorbed language has the original meaning of the language of origin. Jendra (2010) discloses that there are two types of loan words, i.e. required loan words or imported words. Required loan words that are purely absorbed from foreign languages intact emerge because there are no proper words to refer to the words in question. While the second one the imported words are considered as unnecessary loan words, i.e. foreign language words borrowed but in the recipient language there are no words that can represent them.

Loan words can also be called as borrowed words because they are taken from other languages either directly or indirectly. This is needed since there are no proper words to refer to those words or no words that can represent them as stated by Jendra above. Fromkin and Rodman (1998) state that borrowing words from other languages is another important source of new words. The case of borrowing words happens when one language adds to its own lexicon, a word or morpheme from another language, often altering its pronunciation to fit the phonological rules of the borrowing language. The borrowed word, of course, remains in the source language, so there is no need for it to be returned.

Indonesian language has contacted with English language, so in its development, Indonesian language borrows many English words. English loan terms in Indonesian may experience some orthographic and semantic changes. This statement is reinforced by Fromkin and Rodman that a language may gain or lose lexical items and the meaning or semantic representation of words may change, shifting or becoming broader or narrower. Badudu in Kurnianigsih (2010) states the influence of foreign language can be in the form of word structure, sentence, phonemic structure and spelling.

English has spread all over the world in many ways such as through film, documentary, internet, games and media. Media, especially mass media is one of the places where the foreign words are mostly borrowed, as stated by Shepherd (1995) "Mass media is the main source for the foreign forms to be borrowed". Media uses short, simple, 
understanable and solid interesting language. It means that media has responsibility in establishment of a language. And for today, people have more alternative medias to get information such as online news pages on the internet. Therefore some English loan words are used fast and widely due to people's activities which always use internet supporting their activities.

The development of information which is very fast and dynamic makes people always try to update their knowledge. Meanwhile, the ease of accessing information quickly becomes a special reason for humans to obtain information or news via the internet. Today, the use of English can be found in various forms or varieties. One of them is in the variety of journalism. The use of English in a variety of journalistic languages may be due to the difficulty of finding a suitable word equivalent in Indonesian or more concerned with practical and interesting writing presentations. The health articles in online news pages are examples of many articles that contain both English-language elements and words. Many English words are used to convey health related information. The use of English in Indonesian health articles some of which exist as a whole or whole absorption or uptake of adaptation
Health is one of the topic which is needed for people today. Most people are aware about their lives since they care about their lifestyles. For this reason, therefore they try to find out the information about health. And of course, it can be founded on the internet easily.

This study discusses the absorption of English words into the Indonesian language, which is called loan word or borrowed word, especially in the field of health contained in the media journalism of the internet on news pages detik.com, kompas.com and viva.com. The focus of the research is the English word absorption forms and the meaning of the English word absorption that comes in Indonesian language health articles. The formulation of the problem in this research is how the use of English word absorption in health articles in Indonesian language and the meaning contained in the English word.

\section{METHODS}

This research is a qualitative research by using descriptive method with content analysis technique. Crowl (1996) states that qualitative research method are used to examine questions that can best be answered by verbally describing how participants in a study perceive and interpret various aspects of their enviroment. It aims to 
describe the results of data analysis in the form of documents contained in health articles on online news pages, namely: detik.com, kompas.com and viva.com.

The population of this study is all the elements and words of English uptake in health articles contained on the online news page of detik.com, kompas.com and viva.com. The data of documents published by the news page for 1 week from October 16 to October 22, 2017, are then collected, recorded, identified, analyzed, and presented the results of the discussion. The technique of data collection used in this article is documentary. Document is using written materials as a basis for the research. The words are taken from health articles on online news pages.

After the data are collected, they are identified, classified, and analyzed.

a. Table 1

Word grouping based on the word form

\begin{tabular}{|l|l|l|l|l|}
\hline \multicolumn{4}{|c|}{ WORD FORM } & \\
\hline Noun & Verb & Adjective & Adverb & Total \\
\hline 425 & 82 & 96 & 3 & 606 words \\
\hline $70.13 \%$ & $13.50 \%$ & $15.84 \%$ & $0.49 \%$ & $100 \%$ \\
\hline
\end{tabular}

The data are identified then they are classified and analyzed into several categories, they are word form; morphological and phonological process. According to Sudjana (1996) the formula for counting the loanwords rate for each parts are :

$$
\begin{aligned}
& \mathrm{P}=\frac{\mathrm{F}}{\mathrm{N}} \times 100 \% \\
& \mathrm{P}=\text { percentage } \\
& \mathrm{F}=\text { frequency of word } \\
& \mathrm{N}=\text { total of word }
\end{aligned}
$$

And table is used to know the total percentage calculation from each category.

\section{FINDINGS}

From some health articles taken as data source, 606 loan words or borrowed words are obtained with details as follows: 
The first table shows the grouping of word form. From 606 loan words, there are several word forms found, they are: noun, verb, adjective and adverb. From the table it is known that there are 425 words $(70.13 \%)$ that function as nouns, 82 words $(13.50 \%)$ serve as verbs, 96 words (15.84\%) serve as adjective, and 3 words $(0.49 \%)$ serve as adverb.

\section{b. Table 2}

Word grouping based on the morphological process

\begin{tabular}{|l|l|l|l|}
\hline \multicolumn{2}{|l|}{ MORPHOLOGICAL PROCESS } & \\
\hline Affixation & Reduplication & Abbreviation & Total \\
\hline 94 & 7 & 13 & 114 words \\
\hline $82.45 \%$ & $6.14 \%$ & $11.40 \%$ & $100 \%$ \\
\hline
\end{tabular}

Of the three morphological processes, words that experience the most dominant morphology process is affixation i.e. 94 words $(82.45 \%)$, and small number of reduplication which is 7 words $(6.14 \%)$ and abbreviation has 13 words $(11.40 \%)$. In addition, affixation process has detail explanation. It is shown in the following tables below.

\section{c. Table 3}

Here are the details of the affixation process found:

\begin{tabular}{|l|l|l|l|l|l|l|l|}
\hline Prefix & \multicolumn{5}{|l|}{} & Suffix & \\
\hline Ber- & Ter- & Me- & di- & Pe- & Nge- & -nya & Total \\
\hline 15 & 5 & 15 & 15 & 5 & 2 & 10 & 67 words \\
\hline $22.38 \%$ & $7.46 \%$ & $22.38 \%$ & $22.38 \%$ & $7.46 \%$ & $2.98 \%$ & $14.92 \%$ & $100 \%$ \\
\hline
\end{tabular}

The use of the prefix ber-, me, and di- is very often used to transform the word form into both active and passive verbs. The use of prefixes and suffixes which is often found in me- kan and di - kan is used as a change in the form of active and passive verbs. Prefix ber-, me-, and di - for each category has 15 words $(22.38 \%)$. The use of ter- gets 5 words $(7.46 \%)$. Prefix pe - is 5 words $(7.46 \%)$ and nge- has 2 words 
$(2.98 \%)$. There are only 10 words total of affixation process.

$(14.92 \%)$ with suffix -nya from the

d. Table 4

\begin{tabular}{|l|l|l|l|l|l|l|l|l|}
\hline \multicolumn{2}{|l|}{ Prefix --- Suffix } & $\begin{array}{l}\text { Me---i } \\
\text { Me---kan } \\
\end{array}$ & $\begin{array}{l}\text { Me--- } \\
\text { ing }\end{array}$ & $\begin{array}{l}\text { Me--- } \\
\text { asi }\end{array}$ & $\begin{array}{l}\text { Me--- } \\
\text { isasi }\end{array}$ & di---kan & $\begin{array}{l}\text { Se--- } \\
\text { nya }\end{array}$ & Total \\
\hline 6 & 2 & 5 & 2 & 2 & 2 & 6 & 2 & 27 words \\
\hline $22.22 \%$ & $7.40 \%$ & $18.51 \%$ & $7.40 \%$ & $7.40 \%$ & $7.40 \%$ & $22.22 \%$ & $7.40 \%$ & $100 \%$ \\
\hline
\end{tabular}

The data also shows that there is another morphological process: the combination of prefix and suffix in some words. For me- kan is counted as 6 words (22.22\%), me-kan-nya is 2 e. Table 5 words $(7.40 \%)$ as me-asi, me-ing, meisasi, and se-nya. Me-i is 5 words (18.51\%), and the last di-kan has 6 words $(22.22 \%)$ from the total prefix and suffix process.

Word grouping based on phonological process

\begin{tabular}{|l|l|l|l|}
\hline \multicolumn{2}{|l|}{ PHONOLOGICAL PROCESS } & \\
\hline Adoption & Translation & Adaptation & Total \\
\hline 166 & 45 & 395 & 606 words \\
\hline $27.39 \%$ & $7.42 \%$ & $65.18 \%$ & $100 \%$ \\
\hline
\end{tabular}

From the three processes above, adaptation occupies the highest position with as many as 395 words (65.18\%). Whereas the second

\section{DISCUSSION}

Firstly, the data obtained are analyzed based on the word form category. The word form categories taken from the free encyclopedia are noun, verb, position is adoption, amounting to 166 words (27.39\%). And the lowest position is translation with only 45 words $(7.42 \%)$.

adjective, adverb, pronoun, preposition, conjunction, interjection, and article or more recently determiner. From the nine word forms mentioned, only four categories will 
be used to analyze the loanwords or borrowed words, namely: noun, verb, adjective, and adverb. As it mentioned above, the noun occupies the highest position, that is 425 words $(70.13 \%)$. For example: "akademik" from the English word academic, "ambulans" from the English word ambulance, "efisien" from the English word efficient, etc. The second and third position are occupied by adjective and verb, with $96(15.84 \%)$ and 82 words (13.50\%) respectively. Some verb examples are : English word consult for "konsultasi", control for "kontrol", detect for "dideteksi" and so forth. The adjective form such as: English word accurate represents "akurat" in Bahasa , dependent for "dependen", energetic for "energik". And the least is the word form of adverb which has 3 words $(0.49 \%)$. It means adverb forms are rarely absorbed from English into Indonesian. The examples of adverb form are online for "online" in Bahasa and percent for "persen".

The next is the analysis of loan words based on the morphological process which consists of the parts: affixation, reduplication and abbreviation. The definition of affixation as one of the morphological process from Oxford bibliographies (2014) is a process whereby a bound morpheme, an affix, is attached to a morphological base. Diachronically, the English word affix was first used as a verb and has its origin in Latin: affixus, past participle of the verb affigere, ad- 'to' + figere 'to fix'. Affixation falls in the scope of Morphology where bound morphemes are either roots or affixes. Prefixes (affixes that precede the root) and suffixes (affixes that follow the root) are the most common types of affixes cross-linguistically. Affixes mark derivational (-er in teach-er) and inflectional (-s in teacher-s) changes, and affixation is the most common strategy that human languages employ for derivation of new words and word forms. However, languages vary in the ways they express the same semantics, and if in English the noun biolog-ist is derived from biology through the addition of the suffix -ist, in Russian (and other Slavic languages) the same derivation does not involve the addition of an affix but subtraction of form: biolog-ija 'biology'

$\rightarrow$ biolog 'biologist'. Most languages make an extensive use of affixes (most European, African, Australian, and Amerindian languages are of this type), whereas others (e.g., Vietnamese), hardly do. In languages that use affixes, there is a general preference for suffixes over prefixes. The data about the loan words obtained in this study shows that the affixation happens the most, that is about 94 words. The affixation process is done by adding the prefix and suffix. The use of the prefix ber-, ter, me- di and pe- are very often used to 
transform the word form into both active and passive verbs. There is an exception for the prefix in Indonesian that me - which changes into nge - , for example: "ngerap" which is absorbed or adopted from the English word "rap" and "ngemil" from the English word "meal". And the suffix nya indicates the possession, for instance "apresiasinya". The use of prefixes and suffixes which is often found in me- kan, me - kan - nya, me $-\mathrm{i}$, me - ing, me - asi, me - isasi, di kan, and se - nya is used as a change in the form of active and passive verbs. For example: me - kan (mengaktifkan), me - kan - nya (mempublikasikannya), me - i (mendeteksi), me - ing (memposting), me - asi (mendetoksifikasi), me - isasi (mengkomersialisasi), di - kan (dideklarasikan), pe - an (pengontrolan), and se - nya (setimnya). The prefix in Indonesian sometimes experience some changes or additional based on the root of the word, for instance: me - aktif - kan becomes mengaktifkan, pe - kontrol an becomes pengontrolan, etc.

\section{Another morphological} process is reduplication. Reduplication process shows that some words are used in duplicate forms, here those words mean plural nouns. In this research, there are 7 reduplication words $(6.14 \%)$. And they can be seen in some examples, i.e :

\section{Sel sel :}

.......dan akhirnya system kekebalan tubuh menyerang selsel sehat, hingga menyebabkan ruam merah atau bengkak. (Detik, Oct 19, 2017).

In this sentence, "sel-sel" represents more than one cell.

Fase-fase :

Karena kedua kembar siam itu harus melewati fase-fase medis. (Viva. October 17, 2017).

As same as the previous finding, it can be said "fase-fase" means that there is more than one phase.

The last morphological process is abbreviation. It is a process of abbreviating something. It is founded 13 abbreviation words (11.40\%), such as:

CAC (coronary artery clasification);

Stres yang disebabkan karena olahraga berlebihan, menurut penelitian ini bisa menyebabkan klasifikasi pembuluh darah arteri jantung atau CAC (coronary artery clasification). (Detik, Oct 20, 2017)

IUD (Intra Uterine Device):

Dokter tidak menemukan IUD (Intra Uterine Device) dalam operasi tersebut dan menduga alat itu....(Detik, Oct 20, 2017)

Based on abbreviation process, English abbreviation forms are used to refer some terms in Indonesian, 
because there is no similar word or term to replace them.

The last analysis of the loan words or borrowed words is done by using the phonological process which consists of three process, i.e. adoption, translation and adaptation. As mentioned above that adoption is the process of absorbing foreign language vocabulary taken by the user because it has the same meaning but without changing the way of writing and pronunciation or in other words the word taken exactly the same as the original form. In this case Indonesian has many loan words or borrowed words which are considered as adoption. In this research it is founded 166 adoption words (27.39\%). The spellings and the meanings from the source language are similar in Indonesian, but some of them are different in pronunciation.

For example:

Diet:

banyak orang yang mencari cara untuk membuat berat badan menjadi ideal mulai dari diet ketat hingga melakukan olahraga ( Kompas, Oct 19, 2017)

In English diet /'d $\mathrm{d}$ เət/ is: a special course of food to which a person restricts themselves, either to lose weight or for medical reasons. (Noun)

In Indonesian, diet /diét/ means : aturan makanan khusus untuk kesehatan dan sebagainya (biasanya atas petunjuk dokter);

Fit :

Pakar kesehatan menyebutkan bahwa melakukan perjalanan dengan kondisi yang kurang fit mampu membuat kita mengalami mabuk perjalanan. (Kompas, Oct 18, 2017)

In English, fit /fit/ : in good health, especially because of regular physical exercise. (Adjective)

In Indonesian fit /fit/: keadaan berdaya tahan bagi tubuh untuk melakukan aktivitas fisik.

mineral :

Sedangkan lidah buaya adalah gudang dari 32 vitamin dan mineral dengan ratusan enzim serta nutrisi (kompas. com, Oct 18, 2017)

In English, mineral /'min(ə)r(ə)1/ : an inorganic substance needed by the human body for good health.(Noun)

In Indonesian, mineral/ mi-neral/: zat organik yang dalam jumlah tertentu diperlukan oleh tubuh untuk proses metabolisme normal yang diperoleh melalui makanan sehari-hari;

trauma :

pasalnya pemain senior itu mengalami trauma dada, kepala, dan leher akibat bertabrakan 
dengan pemain setimnya (detik. Oct 16, 2017)

In English, trauma /'traomə/ : a deeply distressing or disturbing experience. (Noun)

In Indonesian, trauma/ trau-ma/: keadaan jiwa atau tingkah laku yang tidak normal sebagai akibat dari tekanan jiwa atau cedera jasmani;

Another process is translation process. In this process, a certain word is translated by finding the similar or the same meaning in both languages, English and Indonesian. There are 45 words $(7.42 \%)$ which experience translation process, such as:

Contact lens :

kehilangan fungsi penglihatan akibat lensa kontak bisa terjadi karena infeksi oleh bakteri. (Detik, Oct 22, 2017)

In English : a thin plastic lens placed directly on the surface of the eye to correct visual defects. (Noun)

In Indonesian : lensa is kaca bulat melengkung (seperti kaca pembesar, kaca potret), kontak is hubungan satu dengan yang lain.

Social media:

fotonya saat menolong seorang kakek tua jadi viral dan mengundang decak kagum netizen usai pengguna Facebook Xiao Xuan membagikannya di media sosial (Detik. Oct 16, 2017).
In English : websites and applications that enable users to create and share content or to participate in social networking. (Noun)

In Indonesian : media is alat (sarana) komunikasi seperti koran, majalah, radio, televisi, film, poster, dan spanduk, meanwhile sosial is berkenaan dengan masyarakat.

Low fat :

susu skim atau rendah lemak, khususnya, justru tidak bagus untuk jerawat. (Detik.Oct 16, 2017)

In English : denoting or relating to food or a diet that is low or relatively low in fat, especially saturated fat.(Adjective)

In Indonesian : rendah is dekat ke bawah; tidak tinggi, and lemak is mengandung lemak atau minyak.

Whereas the adaptation process happens the most. It can be said that adaptation process is a process of foreign language absorption used by users because it has the same meaning with the Indonesian language but the word uptake has already changed rules and rules of writing in accordance with the language that absorbs. And for this process, there are 395 words $(65.18 \%)$ For example:

Allergy:

Alergi sperma sering dikatakan sebagai salah satu penghambat 
kehamilan.(Viva. October 16, 2017)

In English : a damaging immune response by the body to a substance, especially a particular food, pollen, fur, or dust, to which it has become hypersensitive. (Noun)

In Indonesian : keadaan sangat peka terhadap penyebab tertentu (zat, makanan, serbuk, keadaan udara, asap, dan sebagainya) yang dalam kadar tertentu tidak membahayakan untuk sebagian besar orang.

Allergy in Indonesian becomes "alergi", in this process there is only one "l" and the changes of "y"into "i".

Depression:

Depresi biasanya ditandai dengan gejala inti antara lain rasa sedih, murung, hilang minat akan suatu hal. (Viva, Oct 18, 2017)

In English : feelings of severe despondency and dejection.(Noun)

In Indonesian : gangguan jiwa pada seseorang yang ditandai dengan perasaan yang merosot (seperti muram, sedih, perasaan tertekan).

Depression in Indonesian has some changes such as "ss" becomes "s" and "ion" becomes "i".

Doctor :

Sisanya, seperti onkologis (dokter yang mendalami soal kanker), bedah umum, dan bedah plastic mempunyai nilai 3.89. (Detik, Oct 18, 2017)

In English : a person who is qualified to treat people who are ill.(Noun)

In Indonesian : lulusan pendidikan kedokteran yang ahli dalam hal penyakit dan pengobatannya;

The word doctor in Indonesian becomes dokter whereas " $\mathrm{c}$ " changes into " $\mathrm{k}$ " and "o" becomes "e"

Genetic :

berkat kondisi genetik langka polydactyly, hampir sebagian besar anggota keluarga Da Silva lahir dengan satu jari ekstra di tangan dan kakinya (Detik, Oct 17, 2017)

In English : relating to genes or heredity.(Adjective)

In Indonesian : keadaan unggul suatu sifat keturunan yang tampak di dalam penampilan.

Genetic is adapted into genetik by changing "c" into " $\mathrm{k}$ ".

Reproduction :

Dalam terapi reproduksi, cara yang dilakukan adalah menyuntikkan seperma langsung pada sel telur. (Viva. October 16, 2017)

In English : The production of offspring by a sexual or asexual process.(Noun)

In Indonesian : pengembangbiakan 
Reproduction in English is adapted into Indonesian by changing ' $c$ ' into " $\mathrm{k}$ " and the suffix "tion" is omitted.

In adaptation process, there are some adjustments. For example, English words within 'c' or 'ct' are transformed into ' $\mathrm{k}$ ' in Indonesian; 'tion' at the end of English words are written and spoken ' $\mathrm{si}$ ' in Indonesian; 'ph' is changed into ' $\mathrm{f}$ ' in Indonesian; and words in dual spelling are mentioned only one spelling in Bahasa, and so on.

\section{CONCLUSION}

From the findings, it can be concluded that the use of English loan or borrowed words in media, especially online pages is frequently used. The usage of loan word can enrich Indonesian. It aims to describe the idea that cannot be expressed with some existing word in Indonesian. The English words that are loaned or borrowed and used by Indonesian people which are categorized as noun, verb, adjective and adverb experience some processes. The process can be morphological process which is done by adding prefix and suffix or phonological process in which the words are loaned or borrowed by adopting, translating or adapting.

It is founded 606 loan words. Then they are categorized into word form category, loan word in noun form has the highest amount, it is 425 words $(70.13 \%)$, followed adjective form which has 96 words (15.84\%), verb with 82 words (13.50\%) and the last is adverb form with only 3 words (0.49\%).

For morphological process, it can be categorized in some various processes, they are affixation with several prefixes and suffixes such as : ber-as much as 15 words or $(22.38 \%)$; ter-with 5 words $(7.46 \%)$; me- has 15 words $(22.38 \%)$; di- is 15 words $(22.38 \%)$; pe- has 5 words $(7.46 \%)$; nge-is 2 words $(2.98 \%)$; and suffix nya with 10 words (14.92\%). Meanwhile there are also several words which experience both prefix and suffix process for example : there are 6 words $(22.22 \%)$ with me-kan; me-kan-nya has 2 words $(7.40 \%)$; me$\mathrm{i}$ has 5 words $(18.51 \%)$; me-ing; and me-isasi both of them have 2 words (7.40\%); me-asi has 2 words $(9.52 \%)$; di-kan has 6 words $(22.22 \%)$; and senya has 2 words $(7.40 \%)$. In addition, there are some words with reduplication, they are 7 words (6.14\%) and abbreviation process, they are 13 words (11.40\%).

Phonological process occurs into several parts, they are adoption, translation and adaptation. For adoption, there are adaptation with 395 words $(65.18 \%)$, adoption with 166 words $(27.39 \%)$ and translation has 45 words (7.42\%). To sum up, since the interaction among the people happen, there will be process of loan 
word. It can be morphological or phonological process. It is not only

\section{BIBLIOGRAPHY}

Dwi, Lina. et.al . Eds. Artikel Ilmiah Mahasiswa. "An Analysis of Indonesian Borrowings on English- Origin Medical Terms". 2014. Jember: Universitas Jember.

Crowl, Thomas K. 1996. Fundamental of Educational Research. Brown\& Benchmark.

Fromkin, Victoria and Rodman, Robert. 1998. An Introduction to Language. 6th ed. Fort Worth: Harcourt Brace College Publisher.

Gómez, L. 2012. Lexical borrowings in the Colombian online newspaper "El Tiempo" from 1990 to 2012 (Doctoral dissertation). Retrieved from ProQuest Dissertations \& Theses University of Alabama (3539988).

Hardjopawiro, Kunardi., 2005. Pembinaan Pemakaian Indonesian. Surakarta: UNS Press.

Hock, H., H. 1986. Principles of Historical Linguistics. Berlin: Mountin de Gruyter.

Jendra, I. 2010. Sociolingustics, Study of Societies' Language. Yogyakarta: Graha Ilmu

Kurnianingsih, Etik Isna. Research Paper. A Study of EnglishIndonesian Borrowing Words in Daily Need Products. 2010. Surakarta: Muhammadiyah University of Surakarta. because the need but also the luxury.

Kushartanti., et al. 2005. Pesona

Bahasa. Langkah Awal

Memahami Linguistik. Jakarta:

Gramedia Pustaka Utama.

Mesthrie, R. \& Leap, W.L. 2000.

Language Contact 1 :

Maintenance; Shift and Death. In

Introducing Sociolinguistics Ed.

Edinburgh: Edinburgh University Press.

Sekarrosa, Tutriana Ayu Sekarrosa. Research Paper: The English Borrowing Words in Kompas Online Articles. 2014. Yogyakarta: Universitas Gadjah Mada.

Sheperd, Joseph W. 1995. Loanwords: A Pitfall for All Students. The Internet TESL Journal. Published in The Faculty Journal of Aichi Gakuin Junior College, Japan.

Sudjana. 1996. Metode Statistika. Bandung: Tarsito

Thomason, S. 2001. Language Contact. Washington, DC: Georgetown University Press.

Thomason, S. and Kaufman, T. 1988. Language Contact, Creolization, and Enatic Linguistics. Barkeley: University of California Press.

https://en.wikipedia.org/wiki/part_of_s peech

www.oxfordbibliographies.com/view/ document/

https://en.oxforddictionaries.com/ https: https://www.kbbi.web.id/ 